\title{
Putting Their Money Where Their MouTh Is:
}

\author{
The We Mean Business Coalition and the \\ Role of Corporate Governance Within the \\ International Climate Regime
}

\section{Aaron Teater $^{\mathrm{I}}$}

\begin{abstract}
The business community has played an increasingly prominent role in international climate governance since the signing of the Paris Agreement. However, recent corporate scandals, such as those of ExxonMobil and Volkswagen, have cast doubt on the credibility of corporate climate action. This paper thus examines the role of corporate climate governance in the postParis climate regime. Primarily, this paper focuses on the We Mean Business coalition, which brings together the leading business groups on climate action. Through exploration of the coalition's organizational structure, its flagship initiative of RE100, and the mechanisms in which firms internalize climate commitments, the case of We Mean Business demonstrates that there is a credible corporate governance regime which plays a critical role in global efforts to combat climate change.
\end{abstract}

\footnotetext{
1 Aaron Teater is a recent graduate of the Hamilton Lugar School of Global and International Studies at Indiana University, where he majored in International Studies and Spanish with a concentration in diplomacy, security, and governance. As an undergraduate, Aaron had the honor of serving on IU's delegation to the 2018 United Nations Climate Change Conference (COP24) in Katowice, Poland, which inspired his interest in the role of non-state actors within global climate affairs. His other research interests include transnational organized crime, U.S.Latin America relations, and comparative government. This piece was written to satisfy the honors thesis requirement for the International Studies degree.
} 


\section{INTRODUCTION}

Following the adoption of the Paris Agreement in 2015 at the 21st Conference of Parties (COP21), the business community has offered unprecedented support to counter climate change. As governments committed to more ambitious $\mathrm{CO} 2$ reduction targets, a groundswell of support for climate action similarly arose from international non-state actors, such as businesses, cities, and NGOs. ${ }^{2}$

The extent to which the private sector should intersect with climate governance is controversial. More businesses than ever are becoming involved in the efforts to combat climate change, but critics remain skeptical of big business and its commitment to climate action. Even those who were previously optimistic for green business have pivoted. During COP21, Naomi Oreskes and Auden Schendler published an article in the Harvard Business Review titled "Corporations Will Never Solve Climate Change." 3 Having emerged within the green-business movement believing that corporations would occupy an important coalition alongside governments, NGOs, and civil society in the fight against climate change, the authors have since grown pessimistic about the potential for such a reality. Citing the Volkswagen emissions scandal, ExxonMobil's public deceit, and British Petroleum's greenwashing, the authors argue that these revelations "spell the end of the old notion of green business, the idea that a big piece of the environmental fix might come voluntarily from the corporate world." 4 The authors conclude that "the reality is that voluntary corporate greening measures don't achieve scale, and therefore aren't climate solutions... Our new message for executives is this: Empower policy makers to do their job. You do your job and let them do theirs." 5 While the violation of public trust by corporations merits critique, Oreskes and Schendler should not abandon the potential of corporate climate action in the face of a few bad actors. According to the International Renewable Energy Agency (IRENA), companies in the commercial and industrial sectors alone account for 67 percent of the world's electricity usage. ${ }^{6}$ The private sector is simply too important

2 UNFCCC, "Historic Paris Agreement on Climate Change: 195 Nations Set Path to Keep Temperature Rise Well Below 2 Degrees Celsius,” UNFCCC Press, December 13, 2015, https:// unfccc.int/news/finale-cop21.

3 Naomi Oreskes and Auden Schendler, "Corporations Will Never Solve Climate Change," Harvard Business Review, December 4, 2015, https:/hbr.org/2015/12/corporations-will-neversolve-climate-change.

4 Ibid.

5 Ibid.

6 Emma Åberg, and Stephanie Weckend, “Corporate Sourcing of Renewables: Market and 
to take a passive role in global climate governance if the international community is to transition to a more sustainable world.

Therefore, the purpose of this paper is to explore the climate action of the business community, which has been under-appreciated by scholars like Oreskes and Schendler and which remains to be thoroughly discussed within international governance literature. ${ }^{7}$ The question guiding this investigation is as follows: are corporate climate initiatives able to establish a credible governance regime within international climate politics, and if so, how? To answer this question, this paper employs a case study approach that examines the leading corporate climate coalition, We Mean Business, which brings together seven leading private initiatives under a single entity to unify and advance the voice, scope, and impact of the business community. Although technically non-profits, many of the founding organizations of We Mean Business are often comprised of leadership with backgrounds in business, receive funding from businesses, and serve businesses as their target audience. ${ }^{8}$ Thus, categorically speaking, We Mean Business can be considered a corporate entity. Moreover, according to Kenneth Abbott and Duncan Snidal's governance triangle that separates states, NGOs, and firms into different types of regulatory schemes, organizations such as the World Business Council for Sustainable Development (WBCSD), a subsidiary of We Mean Business, may be classified as firm schemes rather than NGOs because of their business and industry self-regulation. ${ }^{9}$ Therefore, We Mean Business and its initiatives represent firm-based governance schemes instead of civil society NGOs due to their significant corporate involvement.

This paper analyzes in detail the organizational structure of We Mean Business, how its governance mechanisms establish credibility in climate affairs, and how firms internalize those governance mechanisms within their

Industry Trends," eds. Stefanie Durbin and Steven Kennedy, REmade Index, 2018.

7 See Milan Babic, Jan Fichtner, and Eelke Heemskerk, "States Versus Corporations:

Rethinking the Power of Business in International Politics," The International Spectator 52.4 (2017): 21.

8 "Our Partners," We Mean Business Coalition, https://www.wemeanbusinesscoalition.org/ partners/.

9 Kenneth Abbott and Duncan Snidal, "The Governance Triangle: Regulatory Standard Institutions and the Shadow of the State," in The Politics of Global Regulation, eds. Walter Mattli and Ngaire Woods (Princeton, NJ: Princeton University Press, 2009), 51-52. 
operations. The case of We Mean Business sheds light on the complex role of the business community in international climate governance and the considerable agency of corporations in climate change. Although Oreskes and Schendler have called for business to take a backseat to policymakers, this paper concludes that the case of We Mean Business demonstrates that there is a credible corporate governance regime advancing climate action within the business community that plays a crucial role in the transition to a more sustainable future.

\section{Literature REVIEW}

According to Furio Cerutti, "only nuclear weapons and climate change deserve the name of global challenges, in as much as they can hit everybody on earth and can be addressed only by universal cooperation." 10 The global scale of the climate change issue raises serious questions for international politics and global governance. As such, there is extensive literature within International Relations (IR) and International Political Economy (IPE) that explores the implications of climate change for interstate relations as well as the policy responses with regard to climate governance. The literature reflects how international climate governance both influences state relations and has evolved in tandem with other global trends that have contributed to the complexity of IR and IPE literature. One trend, the rise of corporate power, has challenged the predominance of states in the global economy. Another trend is the development of global regime complexes that see a myriad of non-state actors (e.g. NGOs, businesses, media, and civil society) assuming greater roles in international policy and decision making. Consequently, the topic of international climate governance sits at the intersection of these trends and, therefore, warrants further study within IR and IPE literature. To situate this analysis within the relevant literature, the following review will discuss the relationship between states and corporations in international politics, the climate change regime complex, and corporate authority in climate affairs.

\section{States and Corporations in International Politics}

Since the late $20^{\text {th }}$ century, multinational corporations (MNCs) have reshaped international politics and challenged the state as the primary actor in

10 Furio Cerutti, “Two Global Challenges to Global Governance,” Global Policy 3.3 (2012): 314 , https://doi.org/10.1111/j.1758-5899.2011.00155.x. 
the global economy. Joseph S. Nye Jr., an early scholar of the role of MNCs in international relations, recognized this shift in global power distribution in his landmark 1974 Foreign Affairs article titled, "Multinational Corporations in World Politics." Nye argues that "multinationals are undoubtedly a large force to be reckoned with," citing that "the three billion dollars of value added annually by each of the top ten multinationals is already greater than the gross national product of some 80 member-states of the United Nations." ${ }^{11} \mathrm{He}$ demonstrates that MNCs influence world affairs both directly and indirectly. Directly, MNCs engage sovereign states outside traditional interstate relations through direct bargains for favorable policies, alliances with poorer states to influence international negotiations, and economic means such as offering new investments or threatening to withdraw. Nye also argues that multinationals play an "unintended" direct role by serving as instruments of influence in interstate relations, such as the U.S. using MNCs to strategically advance its political agenda. ${ }^{12}$ Indirectly, multinationals set the global political agenda through lobbying, guiding the flow of trade and money, and stimulating other actors (e.g. banks, labor organizations, NGOs, etc.) to become more engaged in the decision making process. ${ }^{13}$ Nye's work was a harbinger for scholarly investigation into the MNC's role within international relations. In 1996, Susan Strange published The Retreat of the State, which explores how state authority has diminished amid global economic integration. As a result, other actors have increased their share of economic power, particularly multinationals that may operate across national boundaries. ${ }^{14}$ Strange's argument that states have conceded a share of their economic power to MNCs reinforces Nye's claims that multinationals have increased their influence within global politics.

Given the tighter integration of the global economy since the late 1990s, the concerns of Nye and Strange have only become more salient and complex. According to Parag Khanna's 2016 article, the top twentyfive corporations have more financial power than many countries. ${ }^{15}$ Khanna

\footnotetext{
11 Joseph S. Nye Jr., "Multinational Corporations in World Politics," Foreign Affairs 53.1

(1974): 153, https://www.jstor.org/stable/20039497.

12 Ibid., 155-57.

13 Ibid., 160-61.

14 Susan Strange, The Retreat of the State: The Diffusion of Power in the World Economy (Cambridge, UK: Cambridge University Press, 1996), 46.

15 Parag Khanna, "These 25 Companies are More Powerful than Many Countries," Foreign
} 
highlights the "statelessness" of multinationals, who trade in their national roots for better tax environments and optimized supply chains. American companies, such as GE, ExxonMobil, and IBM, hold trillions of dollars tax-free in offshore accounts and overseas markets. ${ }^{16}$ Despite the continuous rise of multinationals as global powerhouses, Babic et al. note that Strange's challenge to IR scholars has nevertheless had little impact on the discipline, stating "the corporation has yet to emerge as a broadly accepted and systematically analyzed object of research in international politics." ${ }^{17}$ While other frameworks, such as constructivism, may recognize the role of corporations, Babic et al. suggest that firms, in general, remain secondary actors within current IR literature. The authors conclude that corporations should receive attention equivalent to that accorded to states within IR and IPE, noting that major events in the global economy, such as the 2008 financial crisis, cannot be explained through a state-centric approach. ${ }^{18}$ Moreover, they argue that "only a proper analytical focus on corporations as actors, embedded in global power relations, can pave the way for a systematic understanding of their (structural) power in the global system." ${ }^{19}$ Consequently, this analysis of corporations within international climate politics aims to diverge from the state-centric literature and further the understanding of the complex role business plays in global governance.

A recent paper by Tim Bartley propounds corporations as meaningful actors through the lens of political sociology. Bartley argues that corporations play three key roles within global governance: sponsor, inhibitor, and provider. MNCs may sponsor favorable neoliberal trade rules, inhibit regulation in areas such as labor rights and climate change, and directly provide governance in issues like finance, food safety, and environmental justice. ${ }^{20}$ For example, Bartley cites that U.S. companies may act as inhibitors through funding climate denialist campaigns to hobble climate change regulation. On the other hand, he cites IKEA's promotion of the Forest Stewardship Council as an example of

Policy, March 15, 2016, http://foreignpolicy.com/2016/03/15/these-25-companies-are-morepowerful-than-many-countries-multinational-corporate-wealth-power/.

16 Ibid.

17 Babic et al., "States Versus Corporations," 21.

18 Ibid., 39.

19 Ibid.

20 Tim Bartley, "Transnational Corporations and Global Governance," Annual Review of Sociology 44 (2018): 159. 
corporations providing governance in environmental justice. ${ }^{21}$ The ability for MNCs to be simultaneously inhibitors and providers within a given policy arena illustrates the significant variation in how corporations participate in global politics.

Furthermore, John Ruggie presents a framework for classifying three primary ways in which multinationals exert power in international relations: instrumental, structural, and discursive. ${ }^{22}$ Instrumental refers to deploying resources to achieve one's aims (e.g. campaign contributions) whereas structural refers to affecting an outcome without expending resources to achieve it (e.g. threatening to relocate to receive more favorable tax breaks). Lastly, discursive refers to influencing outcomes through shaping public discourse and establishing favorable social norms (e.g. denying climate change to avoid transitioning to greener technologies). ${ }^{23}$ Both Bartley and Ruggie show that corporations have far-reaching influence in international affairs through the various roles they perform across many issue areas. Therefore, this paper closely examines how effectively corporations can exert such influence within the climate governance regime.

\section{The International Climate Regime}

Despite widespread reference to the international climate regime by media outlets, policymakers, and scholars, global climate governance is neither a coordinated effort nor limited only to state governance. Farhana Yamin and Joanna Depledge first introduced the concept of an "international climate regime" in their discussion of the participation of non-state actors in climate governance. While Yamin and Depledge recognized multiple nonstate actors, including corporations, they focused primarily on the United Nations Framework Convention on Climate Change (UNFCCC) and the outcomes of the COP up to 2003. ${ }^{24}$ However, in recent years, scholars have called the efficacy of the international climate regime into question, as inter-

\footnotetext{
21 Ibid., 157.

22 John Gerard Ruggie, "Multinationals as Global Institution: Power, Authority and Relative Autonomy," Regulation and Governance 12.3 (2018): 321.

23 Ibid.

24 Farhana Yamin and Joanna Depledge, The International Climate Regime: A Guide to Rules, Institutions, and Procedures (Cambridge, UK: Cambridge University Press, 2004), 3.
} 
state cooperation and state institutions have been impeded by the conflicting interests of the parties involved. According to Thomas Hickman in his book, Rethinking Authority in Global Climate Governance, relying exclusively on statecentric regimes for global challenges like climate change limits the potential for alternative regimes to provide meaningful governance solutions. ${ }^{25}$ As such, scholars have reconsidered the role of non-state actors as both receivers and providers of governance within the international climate regime.

Particularly, Elinor Ostrom has made progress toward rethinking the state-based approach to global governance. Ostrom relies upon the notion of polycentricity: the existence of multiple centers, or governance units, that wield power within a regime. In Ostrom's report to the World Bank, she argues:

Single policies adopted only at a global scale are unlikely to generate sufficient trust among citizens and firms so that collective action can take place in a comprehensive and transparent manner that will effectively reduce global warming...A polycentric approach has the main advantage of encouraging experimental efforts at multiple levels... and having others also take responsibility can be more effectively undertaken in small- to medium-scale governance units that are linked together through information networks and monitoring at all levels. ${ }^{26}$

Polycentrism inherently requires collective action because non-state actors form their own coalitions and construct solutions that are better tailored to their specific set of needs. For business, Ostrom's argument suggests that an autonomous governance unit will increase trust between policymakers and executives, stimulate sustainable innovation through experimentation, and foster more collaboration with other actors through information networks. Similarly, Robert Keohane and David Victor uphold Ostrom's polycentric approach to climate change through their concept of a "regime complex." They argue that climate governance does not occur within a single unified regime, but within a "regime complex: a loosely-coupled set of specific regimes." ${ }^{27}$ This distinction

25 Thomas Hickmann, Rethinking Authority in Global Climate Governance: How Transnational Climate Initiatives Relate to the International Climate Regime (New York: Routledge, 2016), 5.

26 Elinor Ostrom, A Polycentric Approach for Coping with Climate Change, (Washington, DC: The World Bank, 2009), 1.

27 Robert Keohane and David Victor, “The Regime Complex for Climate Change," Perspective 
of regime and regime complex proves useful, as it suggests that the scope of climate governance extends beyond the UNFCCC. Instead, there are cohorts of actors who establish rules and regulations that vary by country, region, and interest group. Keohane and Victor contend that the climate change regime complex has two advantages over the traditional monocentric regime. First, regime complexes facilitate adaptability of rules to varying conditions, issues, and groups of actors. Second, regime complexes allow for flexibility over time, as they account for various rates of change across countries and political structures (e.g. developing vs. developed). ${ }^{28}$ Affirming Ostrom's polycentric approach to climate change, Keohane and Victor's concept of a regime complex, consisting of smaller-scale governance units, facilitates cooperation among actors and encourages experimental efforts at multiple levels.

Building on the work of Ostrom, Daniel Cole explores the advantages of a polycentric approach to climate change policy while advocating for the "Bloomington School" of political economy. Cole posits that "a polycentric approach to climate governance might provide the best chance we have of accelerating progress toward global climate stabilization by providing more frequent and varied opportunities for major emitting parties to engage in face-to-face communications in bilateral and multilateral fora." ${ }^{29}$ More frequent positive interactions lead to progress by building mutual trust, which increases cooperation and collective action between the various actors within international climate governance. According to Cole, the WBCSD, representing the CEOs of over 200 companies globally, has collaborated with experts from the Stockholm Resilience Centre and the World Resources Institute (WRI) on its "ACTION2020" plan to combat climate change through business solutions. ${ }^{30}$ Having also worked with the World Wildlife Fund (WWF), the International Union for the Conservation of Nature, and the Earthwatch Institute, Cole argues that "the WBCSD's activities should not be dismissed blithely as 'greenwash,' but should be understood as [Adil] Najam has argued, as a serious offer from the private sector to participate in

\footnotetext{
on Politics 9.1 (2011): 7-23.

28 Ibid., 15.

29 Daniel Cole, "Advantages of a Polycentric Approach to Climate Change Policy," Nature Climate Change 5 (2015): 117.

30 Ibid., 116.
} 
finding effective solutions to problems such as climate change." ${ }^{31}$ Therefore, the work of Ostrom and Cole, among others, demonstrates that further research is needed on the role of private actors within the polycentric climate regime. By analyzing how the We Mean Business coalition establishes a credible governance unit, this paper will contribute to the discussion on polycentric approaches to global policymaking and illuminate the dynamics at play within private climate governance.

\section{Corporate Power and Authority in International Climate Governance}

As the environmental movement coalesced in the latter half of the 20th century, corporations became further engaged in policy-making processes, notably in regards to the Montreal Protocol, signed in 1987, and during the Rio Earth Summit in 1992. Additionally, in more recent years, alternative forms of climate governance have emerged beyond the state-based system of international politics. For instance, businesses, environmental NGOs, and international organizations cooperate to develop environmentally friendly norms, rules, and mechanisms of corporate action. ${ }^{32}$ Robert Falkner argues that corporations play four roles in environmental politics. First, corporations lobby in international negotiations to prevent regulations harmful to profits, encourage more businessfriendly policies, and shape regulation to create new markets and encourage innovation. Second, corporations carry out implementation of new regulatory requirements and drive mechanisms forward through technological innovation. Third, corporations shape public discourse by advocating for a more businessfriendly perspective that enhances the public legitimacy of private actors. Finally, corporations self-govern through private norm-building and rule-setting, which involves corporate social responsibility (CSR) mechanisms and partnerships with NGOs and international organizations. ${ }^{33}$ While corporations partake in each of these four roles, it is the latter form of private norm and rule-setting that enables corporations to transition from rule-taker to rule-maker.

In analyzing the shift from public to private environmental governance, Arild Vatn looks at two ways in which corporations set their own rules. One way is through certification in which businesses adopt certain standards to

\footnotetext{
31 Ibid., 116-17.

32 Robert Falkner, Business Power and Conflict in International Environmental Politics (New York: Palgrave, 2008), 7-8.

33 Ibid., 9-10.
} 
signal to consumers that their products and operations are environmentally and socially responsible. Another way is through CSR, which leverages the need for corporations to maintain a positive reputation and brand presence. ${ }^{34}$ While Vatn concludes that certification and CSR are only marginal phenomena due to the conflict between public and private interests, some argue that they fill necessary governance gaps where interstate relations fall short. José Célio Silveira Andrade and José Antônio Puppim de Oliveira point out that private actors view "market-oriented and industry-based selfregulation instruments... [as] the only environmental regulation mechanisms able to respond to the shortcomings of traditional command-and-control state-based regulations." ${ }^{35}$ In fact, Silveira Andrade and Puppim de Oliveira argue that voluntary certification and CSR initiatives are at the forefront of emerging private and hybrid governance regimes, as they tend to evolve into legitimate regulation mechanisms backed by NGOs, cities, governments, and international organizations. The authors use the CDP standards as an example, stating, "While initially designed as a voluntary set of standards, [they] are now recognized as legitimate standards by some governments and IOs (international organizations)." ${ }^{36}$ Founded by 22 investors in the United Kingdom, CDP now has more than 530 investors under its purview, accounting for over \$57 trillion. ${ }^{37}$ The emergence of private initiatives as valid governance mechanisms exemplifies the critical role played by corporations, raising further questions about the diffusion of authority within the international climate regime.

The rise of private initiatives has prompted some scholars to explore how the agency of corporate actors relates to the international climate regime and state governance. Notably, Jessica Green argues that there are two types of private authority at play in international environmental governance: delegated and entrepreneurial. Delegated authority involves states assigning control to private actors through formal governance mechanisms. ${ }^{38}$ By contrast,

\footnotetext{
34 Arild Vatn, "Environmental Governance-From Public to Private?" Ecological Economics 148 (2018): 174-175.

35 José Célio Silveira Andrade and José Antônio Puppim de Oliveira, "The Role of the Private Sector in Global Climate and Energy Governance,” Journal of Business Ethics 130.2 (2015): 377.

36 Ibid., 378.

37 Ibid.

38 Jessica Green, Rethinking Private Authority: Agents and Entrepreneurs in International
} 
entrepreneurial authority does not involve the delegation of power. Instead, private actors create their own rules and it is left to the discretion of other actors to determine whether to adopt them. ${ }^{39}$ Through Green's case studies on the Clean Development Mechanism (delegated) and the Greenhouse Gas Protocol (entrepreneurial), she argues that the state is not retreating, as some IR scholars have warned. Rather, "the way that states are governing appears to be changing: they are enlisting more actors (including international organizations and private actors) to undertake the same task." ${ }^{40}$ Thus, according to Green, as opposed to authority resting solely with the state, there are multiple pockets of authority working in unison. ${ }^{41}$ Hickman furthers this claim by arguing that the emergence of private climate governance is a "reconfiguration of authority that only reinforces the importance of the intergovernmental level." ${ }^{42}$ Hickman explains that "while sub-national, non-profit, and business actors have acquired various authoritative functions in global climate governance over the past few decades, the international climate regime remains the center around which these actors revolve and upon which their initiatives are built." ${ }^{43}$ In maintaining that the state remains a key player among other centers of authority, Green and Hickman's insight reinforces the work of Ostrom and Cole, as well as that of Keohane and Victor in regards to the polycentric nature of the international climate regime. The examination of how private initiatives, such as the We Mean Business coalition, establish alternative forms of climate governance will advance the current literature by furnishing analysis of more recent cases that have emerged since the Paris Agreement in 2015.

\section{Case Study}

Founded in 2014, the We Mean Business coalition sought to unify the world's leading business initiatives on climate change and has since overseen the launch of multiple governance mechanisms to accelerate corporate climate action. Specifically, this paper will discuss one mechanism, the $100 \%$ Renewable Energy initiative (RE100), in further detail below. Given that this initiative

\footnotetext{
Environmental Governance (Princeton, NJ: Princeton University Press, 2014), 7.

39 Ibid..

40 Ibid., 175.

41 Ibid.

42 Hickmann, Rethinking Authority in International Climate Governance, 12.

43 Ibid.
} 
was launched in 2015, it is representative of the current efforts of We Mean Business and the role of private actors in the post-Paris climate regime. While other initiatives exist within the business community, We Mean Business is led by the most prominent leaders in corporate sustainability and has just over 1,000 companies within its network. ${ }^{44}$ To demonstrate how We Mean Business establishes authority and develops credible governance mechanisms, the following section will explore its functional organizational structure, the development, progress, and impact of RE100, and how businesses, in turn, implement climate action within their business model. This section will conclude with an analysis of emerging trends supporting the theoretical foundations discussed in the literature review.

\section{The Functional Structure of We Mean Business}

In its most basic form, We Mean Business is a coalition of coalitions that aims to consolidate the work of the world's leading corporate climate initiatives. The coalition began to take form in 2013 over the course of a series of climate events and conferences during which several corporate climate leaders convened to discuss ways to heighten the collective action of the business community. With COP21 in Paris on the horizon, these business leaders considered the potential for a new international agreement as a pivotal moment for business to increase its influence in policy creation and scale up corporate climate action. ${ }^{45}$ Those involved in these early discussions included Aron Cramer, President of Business for Social Responsibility (BSR); Mindy Lubber, President of Ceres; Mark Kenber, CEO of The Climate Group; Nigel Topping, current CEO of We Mean Business; Paul Dickinson, Executive Chair and founder of CDP; and Peter Bakker, President of WBCSD. Accompanying the leaders of the various initiatives were Hannah Jones, then Chief Sustainability Officer (CSO) of Nike, and Steve Howard, then CSO of IKEA and current co-Chair of We Mean Business. ${ }^{46}$ From these discussions, three

\footnotetext{
44 “Companies," We Mean Business, 2019, https:/www.wemeanbusinesscoalition.org/ companies/.

45 Joel Makower, "Two Steps Forward: A Powerhouse Corporate Climate Coalition Says, 'We Mean Business,"' GreenBiz, June 9, 2014, https:/www.greenbiz.com/blog/2014/06/09/ powerhouse-climate-coalition-we-mean-business. 46 Ibid.
} 
objectives of We Mean Business emerged: coordinate efforts to avoid duplicating activities, encourage collaboration among the initiatives to increase the quantity and quality of carbon reporting, and develop a common set of principles to advocate for during the policymaking process. ${ }^{47}$

The collaboration between these leaders of corporate climate groups enabled the business community to increase its role in the policymaking process and counter the voice of businesses opposed to climate action. According to Howard, "there are a lot of good and credible NGOs and business groups working on climate change for more than 10 years, but we were still politically stuck. The proactive, progressive business voice wasn't breaking through. Meanwhile, the business voice that wants to maintain the status quo has been well-organized, well-funded." ${ }^{8}$ In other words, the consolidation of the most influential corporate climate initiatives served to combat the negative image of business among climate activists and show policymakers that corporations are prepared to meaningfully participate in shaping a more sustainable world. The unique structure of We Mean Business as a coalition of corporate climate initiatives that maintain their operational autonomy allows the organization to increase the role of the private sector within the international climate regime and achieve greater authority through the collective influence of the myriad actors under its purview.

While We Mean Business brings together hundreds of actors, its organizational structure is designed to facilitate cooperation and mitigate tension between the differing interests of the many players involved. One concern with We Mean Business from the outset has been the difficulty of prompting hundreds of businesses, executives, and corporate climate groups to work together collaboratively. In his review of We Mean Business at the time of its founding, Joel Makower, Chairman and Executive Editor at the GreenBiz Group, posited the question: "Is it even possible for all these groups-and the 500 or so mostly large companies they represent-to have a unified view on anything, let alone climate policy?" 49 The concern that a large number of actors may hinder cooperation is a common critique in IR literature. As Keohane and Ostrom acknowledge, "In international relations, it has almost become conventional wisdom that increasing the number of players magnifies the

\footnotetext{
47 Ibid.

48 Ibid.

49 Ibid.
} 
difficulty of cooperation." ${ }^{50}$ However, Ostrom and Duncan Snidal explain that "an important aspect of institutional design...has to do with partitioning relatively large numbers of actors into smaller subsets, which may be able to meet frequently face to face... or to negotiate on issues that particularly concern them, before returning to negotiate with the larger set of participants." ${ }^{51}$ This structure facilitates the meaningful engagement of actors in the process and allows subgroups to focus on their respective objectives without interference from the larger set. This polycentric configuration is reflected by We Mean Business, for the various initiatives may pursue their own agendas, maintain their respective organizational structures, and manage their unique relationships with stakeholders. The business groups may collaborate on similar projects and align on policy recommendations without forcing the disparate players to forfeit their autonomy. Thus, We Mean Business functions to enhance cooperation within the business community despite the substantial rise in the number of actors at play.

In addition to its polycentric design, We Mean Business further builds cooperation amid a greater number of participants by facilitating knowledge sharing. Decreased information barriers and increased transparency promote cooperation between large sets of actors in international relations. Keohane and Ostrom, citing Hackett et al. and Libecap, explain that "extensive common knowledge and ease of information provision facilitate cooperation, while private information and barriers to communication make it much more difficult." 52 For the We Mean Business coalition, the creation of a platform through which the leaders of the various initiatives routinely meet, encourages them to share best practices, brainstorm ideas, and improve overall awareness of what their counterparts are working on. For example, the GreenBiz 2019 conference hosted by WBCSD brought together 100 company executives and industry experts, providing a forum for discussion of recent business solutions to drive long-term value creation and improve environmental governance practices. ${ }^{53}$ One reason the progressive business community was politically

\footnotetext{
50 Robert Keohane and Elinor Ostrom, eds., Local Commons and Global Interdependence: Heterogeneity and Cooperation in Two Domains (London: Sage Publications, 1995), 6.

51 Ibid., 21.

52 Ibid., 21-22.

53 See "Join Us at GreenBiz," WBCSD, http://promo.wbcsd.org/greenbiz-2019/.
} 
stuck, as Howard explained, was because each initiative was being pulled in a different direction without full awareness of the others' activities. ${ }^{54}$ In effect, the reduction in information asymmetries increases cooperation among the initiatives that would have otherwise been operating independently of one another.

Moreover, the common knowledge and transparency provided by We Mean Business allow individual firms to more strategically engage in corporate climate action. Through the We Mean Business website, the climate action commitments of each initiative, such as RE100, are all consolidated in one place. ${ }^{55}$ This gives businesses the ability to see the full range of options available to them, enabling them to strategically select the initiatives to which they commit. In the past, the lack of information sharing limited a firm's involvement with climate initiatives. However, through We Mean Business, firms are more easily able to diversify their climate action portfolio, interact with multiple initiatives at once, and receive credible information from a single authoritative body. For example, since 2016, the H\&M Group has made seven different climate action commitments through We Mean Business: RE100, Science-based Targets initiative (SBTi), carbon pricing, removal of deforestation in the supply chain, doubling energy productivity through EP100, public reporting of climate change information, and responsible engagement in climate policy. ${ }^{56}$ In 2018 , the firm reached the highest possible score in the Dow Jones Sustainability Index (DJSI) in the areas of Quality and Recall Management, Social Reporting, Environmental Reporting, as well as the highest industry score in Supply Chain Management. ${ }^{57}$ As more firms increase their engagement in this way, they provide We Mean Business and its subsidiaries with more information on firm activities,

\footnotetext{
54 Makower, "Two Steps Forward."

55 See https://www.wemeanbusinesscoalition.org/take-action/.

56 “Companies: H\&M Hennes and Mauritz," We Mean Business, 2019, https://www. wemeanbusinesscoalition.org/companies/\#pageNum=8.

57 The Dow Jones Sustainability Index invites approximately 4,500 companies from the S\&P Global BMI and reviews all companies that have been analyzed through the SAM Corporate Sustainability Assessment. Based on sustainability scores, the DJSI conducts a rules-based selection process of the top 10 percent most sustainable companies in each industry to be included in the final index. According to research from Sarah Elena Windolph, DJSI was the highest ranked index among sustainability experts despite the fact that only 48 percent classified it as "highly trusted." Sarah Elena Windolph, "Assessing Corporate Sustainability Through Ratings: Challenges and Their Causes," Journal of Environmental Sustainability 1.1 (2011): 73; H\&M Group, "Sustainability Reporting: Indexes and Rankings," H\&M Group, https:// sustainability.hm.com/en/sustainability/about/what-others-say/indexes-rankings.html.
} 
which can be used to cooperate further with businesses and refine the structure of their climate action commitments. Therefore, We Mean Business effectively facilitates cooperation among many actors within the private climate governance regime in such a way that was not possible prior to its formation.

To further illustrate the role of We Mean Business within private climate governance, the following section explores the RE100 initiative. The analysis below explains how the initiative establishes credibility within corporate climate governance and how We Mean Business has enabled its rise to prominence.

\section{RE100}

RE100 is an initiative founded by The Climate Group in partnership with CDP — both subsidiaries of We Mean Business — to "engage, support, and showcase large, influential businesses committed to $100 \%$ renewable electricity." ${ }^{58}$ The initiative was launched at Climate Week NYC 2014, a week-long climate change conference organized by The Climate Group and sponsored by the United Nations and the City of New York. Bringing together business leaders, policymakers, and government officials, the conference celebrated current climate action and prompted collaborative discussion on how to scale impact and accomplish more. Founded by IKEA Group and Swiss Re, RE100 was comprised of 11 other committed companies such as H\&M, Nestlé, Unilever, and Mars (the only U.S. firm). Since 2014, RE100 has expanded to include over 200 companies, including Apple, Facebook, General Motors, Google, JP Morgan Chase, Nike, Walmart, and many other Global 500 firms and industry leaders. Companies from China, India, Mexico, the Middle East, and Africa have also joined the initiative. ${ }^{59}$ The rapid adoption of RE100 has seen the initiative surpass its original target of 100 companies by 2020 three years early, demonstrating its widespread influence within the business world. ${ }^{60}$

Firms need to satisfy a number of criteria for membership within

\footnotetext{
58 "World First as 100 Multinationals Target 100\% Renewable Electricity," RE100, July 10, 2017, http://there100.org/news/14257837.

59 “Companies," RE100, 2019, http://there100.org/companies.

60 "World First as 100 Multinationals Target 100\% Renewable Electricity."
} 
RE100. ${ }^{61}$ To join, companies must:

1. Be "influential," in that they are a recognized brand, member of the Fortune 1000, or have a significant power footprint that exceeds 100 GWh

2. Be willing to make a public commitment to sourcing $100 \%$ renewable energy across all operations as defined by the Greenhouse Gas Protocol

3. Have a renewable power strategy that has credible deadlines with a minimum of $30 \%$ by $2020,60 \%$ by $2030,90 \%$ by 2040 , and $100 \%$ by 2050

4. Report their progress annually through the RE100 reporting spreadsheet, which outlines total electricity consumption and total renewable use data subject to third-party verification

Additionally, the RE100 Technical Criteria outline the options available to companies seeking to transition their energy consumption, such as the purchase of on-site installations, direct lines from off-site suppliers, direct procurement from off-site grid-connected generators, contracts with suppliers, and the purchase of unbundled energy attribute certificates. ${ }^{62}$ The membership standards and technical criteria are overseen by the RE100 Technical Advisory Group, which consists of third-party experts from the CDP, Center for Resource Solutions, RECS International, Rocky Mountain Institute, U.S. Environmental Protection Agency, and the WRI. ${ }^{63}$ As sustainability experts have criticized private indices and initiatives for lack of credible information, the formation of the Technical Advisory Board is an effort to validate the initiative in the eyes of external stakeholders.

As RE100 has gained traction among leading firms, the UN and other international organizations have recognized it as a leading initiative for driving corporate climate action. Upon hitting the 100-member milestone in 2017, Executive Secretary of the UNFCCC Patricia Espinosa said, "This would not be happening without leadership — and not just at the level of a CEO or Company Board. It has been a huge collective effort of people at all levels... Moreover, this

\footnotetext{
61 “Joining Criteria," RE100, January 2017, http://media.virbcdn.com/files/45/ db8335e1 ef4b851c-RE100JoiningCriteria.pdf, 1-2.

62 "RE100 Technical Criteria: Technical Note on Renewable Electricity Options," RE100, January 2018, http://media.virbcdn.com/files/73/4c55f6034585b02f-RE100TechnicalCriteria. pdf, 2.

63 Ibid., 6.
} 
' 100 moment' is part of an alliance of inspiring actions flourishing across the globe by corporations." ${ }^{4}$ Echoing Espinosa's sentiments, Dominic Waughray of the World Economic Forum stated, "RE100 shows the potential for business to lead, and collectively shift markets to a more sustainable future." ${ }^{65}$ It is significant that RE100 has gained recognition from the UNFCCC, the World Economic Forum, and other policymakers despite its independence from the traditional governance channels of the UN and state governments. It is important to note that the recognition of RE100 by Espinosa and Waughray may have been a result of the close relations between international governance institutions and private initiatives, such as The Climate Group and CDP, providing policymakers with unique insight into the work of RE100. In fact, gaining support from actors outside the business community is part and parcel of the strategy to establish RE100 as a credible governance mechanism within international climate politics.

Along with leveraging the voices of world leaders, The Climate Group and CDP also rely on leadership from the initiative's member corporations to advance the business case for 100 percent renewable electricity. For some of the companies who join the initiative, RE100 publishes a case study on why the company decided to join, its specific goals and progress, and why it thinks RE100 is a worthwhile investment. By publishing the case studies, RE100 communicates the efforts of the specific company to the public, while also putting pressure on other companies to follow suit. As Steve Howard, CSO of IKEA, explains, "actions speak louder than words and well-known names can demonstrate the strong business case for going 100 percent renewable." 66 In other words, showcasing the commitments of industry leaders signals to other companies that transitioning to more sustainable practices is a rising industry strategy that is necessary to remain competitive. Mike Power, COO for Technology and Operations at DBS Bank, explains that "companies need to 'get with the program now' or risk losing relevance to their customers." ${ }^{67}$

\footnotetext{
64 "100 Multinationals Commit to 100\% Renewable Electricity," United Nations Framework Convention on Climate Change, July 11, 2017, https://unfccc.int/news/100-multinationalscommit-to-100-renewable-electricity.

65 "World First as 100 Multinationals Target 100\% Renewable Electricity," RE100, July 10, 2017, http://there100.org/news/14257837.

66 "IKEA," RE100, June 2016, http://there100.org/ikea/.

67 Constant Alarcon, Sam Kimmins, Marie Reynolds, Eleanor Dinnadge, Shailesh Telang,
} 
In addition, RE100 member companies cooperate with one another, sharing best practices and collaborating to find new, innovative approaches. Such collaboration establishes an exclusive network between RE100 member firms, creating business opportunities inaccessible to non-members. Altogether, the benefits to a firm's public image, establishment of industry norms, and access to a unique network of industry leaders encourage companies to buy in to RE100 and help explain the over two-fold increase in member companies since $2017 .{ }^{68}$

Furthermore, RE100 shapes renewable energy policy at the national and international levels. According to results from CDP's Climate Change Questionnaire, policy was the most cited barrier to sourcing renewable electricity. ${ }^{69}$ The initiative's 2018 annual report states, "RE100 is committed to helping members overcome those barriers by making the case to national governments for simplifying access; enabling markets where direct purchase of electricity is possible for companies_-giving them control over their energy supply_and where traceability of renewable electricity is guaranteed." 70 Beyond assisting individual member companies in lobbying for more favorable policies, collectively, RE100 forms a unified voice for businesses committed to transitioning their electricity sources and opening up more energy markets to accelerate the transition. Speaking to the collaborative power of RE100, Michelle Patron, Director of Sustainability for Microsoft, said: "RE100 brings us all together, makes us a market power and our political power, our advocacy a lot stronger than any individual company alone."71 In effect, the collective influence of RE100 enabled its involvement in the negotiations of the EU Renewable Energy Directive, which ultimately resulted in securing a 2030 renewable energy target and a legal framework for PPAs (Power Purchase Agreements). ${ }^{72}$

and Chiara Gilbert, "Approaching a Tipping Point: How Corporate Users are Redefining Global Electricity Markets," RE100 Progress and Insights Report, January 2018, http://media.virbcdn. com/files/97/8b2d4ee2c961f080-RE100ProgressandInsightsReport2018.pdf, 21.

68 Marie Reynolds, Jessy Field, and Sam Kimmins, "Accelerating Change: How Corporate Users Are Transforming the Renewable Energy Market," ed. Will Brittlebank, RE100 Annual Report 2017, https://www.theclimategroup.org/sites/default/files/devel-generate/kes/re100_annual_ report_2017.pdf, 3; "Companies," RE100, http://there100.org/companies.

69 Alarcon et al., "Approaching a Tipping Point," 22.

70 Ibid., 23.

71 Ibid.

72 Power Purchase Agreements are contracts established between privately-owned suppliers and purchasers of electricity for a specific project connected to the power grid. The purpose of a PPA is to finance a project by securing a revenue stream and outlining the contractual terms. PPAs 
Member firms have also advocated on behalf of RE100, as Mars, Unilever, and Fujitsu promoted the economic benefits of corporate sourcing of renewables at the Australian Federal Parliament in October 2018. ${ }^{73}$ Many member firms were also involved in the Talanoa Dialogue at COP24 in Katowice, Poland. ${ }^{74}$ As RE100 has established a certain level of credibility with policymakers, this may be leveraged in the creation of governance mechanisms by states and intergovernmental bodies that subsequently impact renewable energy adoption on a broader scale.

By attracting more large companies to commit to 100 percent renewable electricity and influencing renewable energy policy, RE100 aspires to make renewables the default energy source for business. RE100 aims to increase demand for renewable energy, which will lower the market costs for such technology. In turn, lower costs will make renewable energy more accessible and attractive for businesses, cities, and governments to adopt. As mentioned above, companies in the commercial and industrial sectors alone account for about 67 percent of the world's electricity usage. ${ }^{75}$ Moreover, in a Special Report on $1.5^{\circ} \mathrm{C}$, the Intergovernmental Panel on Climate Change (IPCC) found that renewables will need to make up between 70 to 85 percent of electricity by 2050 to not exceed the $1.5^{\circ} \mathrm{C}$ benchmark. ${ }^{76} \mathrm{RE} 100$ cites the

vary by country and region depending on local policies and regulations. See Emily Farnworth, "Briefing Report 2015," ed. Clare Saxon, RE100, January 2015, http://media.virbcdn.com/ files/d4/0d785368ea4e15c5-RE100briefing-reportre100websitev3.pdf, 6.

73 Elanor Dinnadge, Constant Alarcon, and Marie Reynolds, "Moving to Truly Global Impact: Influencing Renewable Electricity Markets," RE100 Progress and Insights Report, November 2018, http://media.virbcdn.com/files/fd/868ace70d5d2f590-RE100ProgressandInsi ghtsAnnualReportNovember2018.pdf, 10.

74 “COP24: Leading Companies Demonstrate Climate Action, Call for Policy Ambition," We Mean Business, December 12, 2018, https:/www.wemeanbusinesscoalition.org/blog/cop24leading-companies-demonstrate-climate-action-call-for-policy-ambition. The Talanoa Dialogue is an inclusive, participatory, and transparent forum for discussion on climate action that brings together leaders from government, civil society, business, religion, NGOs, Indigenous peoples, and other groups to share stories and experiences on climate action. See "What is Talanoa?" Talanoa Dialogue Platform, 2018, https://talanoadialogue.com/background.

75 Åberg and Weckend, "Corporate Sourcing of Renewables," 3.

76 Valérie Masson-Delmontte, Panmao Zhai, Hans-Otto Pörtner, Debra Roberts, Jim Skea, Priyadarshi Shukla, et al., eds., "Global Warming of $1.5^{\circ} \mathrm{C}$ : An IPCC Special Report on the Impacts of Global Warming of $1.5^{\circ} \mathrm{C}$ Above Pre-Industrial Levels and Related Global Greenhouse Gas Emission Pathways, In the Context of Strengthening the Global Response to 
data provided by IRENA and the IPCC as motivation for its work and sees itself as a leader in the energy transition. Last year, RE100 earned recognition as the "Environmental Campaign of the Year" at the BusinessGreen Leaders Awards and as one of seven leaders on UN Sustainable Development Goal 7 at a Seven for 7 event hosted by Sustainable Energy for All. ${ }^{77}$ These awards reveal the considerable acknowledgment that RE100 has gained within the proactive business community despite its relatively short existence.

Going forward, RE100 aims to continue engaging businesses in its current network and to expand into additional sectors and regions with untapped potential. ${ }^{78} \mathrm{RE} 100$ is further shifting its attention to supply chains which emit, on average, four times the amount of a firm's direct operations. While RE100 has established itself as a credible governance mechanism within international climate affairs, it also is a key actor in the renewable energy transition through its representatives' and member companies' lobbying. Accordingly, the example of RE100 illustrates We Mean Business' approach to climate action commitments and carries significant implications for the state of private climate governance post-Paris.

Within the context of the IR and IPE literature, RE100 supports the theories of private authority and global governance. Specifically, RE100 directly aligns with Falkner's four roles of business in environmental politics. RE100 lobbies for more favorable renewable energy frameworks to create new markets, helps corporations implement new regulatory standards through its technical advisory board, shapes public discourse by advancing the business case for renewables through case studies and media features, and allows the corporate community to self-govern by adopting a mechanism that has been created outside the jurisdiction of government regulation. The lobbying of RE100 and its member firms also supports Hickman's conclusion that, despite the emergence of private climate governance, the traditional partnership of governments and international organizations remains the central focus that the myriad other actors rely on. The companies who join RE100 do not seek abrogation of the Paris

the Threat of Climate Change, Sustainable Development, and Efforts to Eradicate Poverty," IPCC Special Report, 2018, 15.

77 "RE100 Wins Environmental Awareness Campaign of the Year Award," RE100, June 28, 2018, http://there100.org/news/14279497; "RE100 Leading the Way on Accessible and Sustainable Energy for All,” RE100, July 17, 2018, http://there100.org/news/14280060.

78 Dinnadge et al., "Moving to Truly Global Impact," 10. 
Agreement. Rather, they aim to work in tandem with the UNFCCC and its counterparts to accelerate climate action. In fact, when U.S. President Donald Trump announced plans to withdraw from the Paris Agreement in 2016, over 2,000 businesses and investors signed on to the "We Are Still In" declaration, which was coordinated by We Mean Business, its subsidiaries, and a litany of other sustainability NGOs to reaffirm the U.S.'s continued commitment to combating climate change. ${ }^{79}$

While RE100 reinforces the work of Falkner and Hickman, it also furthers Green's theory of entrepreneurial authority in which private actors create their own rules, and it remains up to other actors whether they adopt them. ${ }^{80}$ RE100 aligns with Green's framework of entrepreneurial authority due to its formation by business groups and corporate NGOs without involvement of the state. While Green based her argument on the GHG Protocol established in the late 1990s, the current efforts of We Mean Business illuminate how the practice of entrepreneurial authority has gained greater prominence in the past two decades as private actors increase engagement within global climate governance. Finally, RE100 substantiates Ostrom's polycentric approach to climate change. Given that We Mean Business is its own governance unit, RE100 demonstrates how mechanisms created outside the state-based system may encourage cooperation and trust within the business community because the rules are written by business leaders, for business leaders. Put simply, RE100 is the type of initiative Ostrom advocates for in her polycentric approach: it is tailored to its specific subset of actors (corporations) and encourages them to assume greater responsibility for their actions than they otherwise would have under restrictive regulation at the global level.

Although RE100 supports multiple theories of private authority in global governance, it is not without its shortcomings. One notable critique is that RE100 targets only "influential" and large companies. On the surface, this decision appears to be positive since industry leaders usually have the largest market cap and their business decisions affect the strategies of their industry counterparts. However, according to research from Sarah Elena Windolph on the challenges of assessing corporate sustainability, selecting only the largest

79 "About," We Are Still In, https://www.wearestillin.com/about.

80 Green, Rethinking Private Authority, 7. 
companies ultimately leads to bias. ${ }^{81}$ Windolph explains that focusing solely on the "best in class" companies means that the target audience is investors and that their primary motivation is whether sustainability can turn a profit. Moreover, Windolph argues that because small- to medium-sized firms are left out, "sustainability leaders may not be identified by this procedure, since the raters possibly do not even include them in the sample or they do not take part in the rating." ${ }^{2}$ What this means for RE100 and We Mean Business more generally is that the work of the initiative is inherently tethered to and contingent upon stakeholder interests as opposed to being representative of independent climate action. Whether profit maximization and meaningful climate action may sustainably coincide in the future, however, is what will determine the long-term viability of We Mean Business as a credible governance regime within international climate politics.

\section{Internalizing Climate Action}

As RE100 has grown in prominence within private climate governance, the concern that these voluntary corporate governance mechanisms are merely symbolic begs the question: how do these initiatives become embedded in a firm's operations and affect its profit margins and overall competitiveness? While scholars and critics have argued that sustainability efforts are no more than corporate "greenwashing," there is in fact a structured approach to analyzing how climate commitments influence a company's internal operations. ${ }^{83}$ According to Philip Mirvis and Bradley K. Googins, who adopt Jean Piaget's developmental theory, there are five stages in the development of corporate citizenship: elementary, engaged, innovative, integrated, and transforming. ${ }^{84}$ The authors define corporate citizenship as "balancing the expectations of stakeholders - such

\footnotetext{
81 Windolph, “Assessing Corporate Sustainability Through Ratings," 66.

82 Ibid.

83 Michelle Rodrigue, Michel Magnan, and Charles Cho, "Is Environmental Governance Substantive or Symbolic?: An Empirical Investigation," Journal of Business Ethics 114.1 (2013): 107. Greenwashing refers to the practice of corporations appearing to be environmental stewards as a way to divert attention away from their unsustainable practices. See Bruce Watson, "The Troubling Evolution of Corporate Greenwashing," The Guardian, August 20, 2016, https:// www.theguardian.com/sustainable-business/2016/aug/20/greenwashing-environmentalism-liescompanies.

84 Philip Mirvis and Bradley K. Googins, Stages of Corporate Citizenship: A Developmental Framework (Chestnut Hill: The Center for Corporate Citizenship at Boston College, 2007), 3.
} 
as shareholders, employees, communities, governments, and activists - with the management of a successful business." ${ }^{85}$ Other scholars simplify this framework to just three stages: compliance, efficiency, and innovation. ${ }^{86}$ Mirvis and Googins argue that the initial stages of corporate citizenship are rudimentary in that they focus only on complying with laws and industry standards as a way to defend the firm's reputation. In subsequent stages, firms tend to "wake up" to the expectations of society by implementing internal policies that go beyond the law, active public relations, and philanthropic activities, while still remaining reactive to social and environmental trends. ${ }^{87}$ In the later stages of development, companies transition from being reactive to proactive. They broaden their agenda by launching an array of sustainability and social impact programs and become leading innovators in the stewardship of social and environmental issues. In fact, the authors explain that corporate leaders in the advanced stages of sustainability "partner extensively with other businesses, community groups, and NGOs to address problems, reach new markets, and develop local economies." 88 Mirvis and Googins' framework provides insights into We Mean Business and the influence of its initiatives on internal operations because the companies who commit are often in these latter stages of development.

Further, the rise of the Chief Sustainability Officer (CSO) is another important trend that contextualizes the framework of Mirvis and Googins. Although companies had sustainability positions as early as the 1980s, Dupont was the first company in the U.S. to establish the CSO position, appointing Linda Fisher as its CSO in 2004. ${ }^{89}$ Since then, the number of CSO positions within U.S. publicly traded companies has risen to 44, with more than half being created after $2014 .{ }^{90}$ Companies who have created the position tend

\footnotetext{
85 Ibid., i.

86 Kathleen Miller and George Serafeim, "Chief Sustainability Officers: Who Are They and What Do They Do?," in Leading Sustainable Change: An Organizational Perspective, eds. Rebecca Henderson, Ranjay Gulati, and Michael Tushman (Oxford, UK: Oxford University Press, 2015), 197.

87 Mirvis and Googins, Stages of Corporate Citizenship, 6-7.

88 Ibid., 12.

89 "CSO Backstory: How Chief Sustainability Officers Reached the C-Suite," Weinreb Group, September 2011, https://weinrebgroup.com/wp-content/uploads/2011/09/CSO-Back-Storyby-Weinreb-Group.pdf, 6.

90 "Updated CSO Research,” Weinreb Group, December 2018, https://weinrebgroup.com/cso-
} 
to be industry leaders with large social and environmental footprints, such as Nike, AT\&T, Verizon, Coca-Cola, Walmart, and Dow. To shed light on this trend, Kathleen Miller, CEO of Miller Consultants, and George Serafeim, from Harvard Business School, investigated the role of CSO at different stages of corporate social development. They found that CSOs hold greater authority in more advanced stages of sustainability, often reporting directly to the CEO and integrating the strategic approach to social and environmental issues throughout the firm's entire operations. ${ }^{91}$ Moreover, companies with CSO positions were more likely to have a dedicated sustainability committee on the Board of Directors, providing the CSO with greater influence over the leadership's strategic decisions. ${ }^{92}$ Consequently, the rise of the CSO is an important trend because it reflects the leadership within the firm that drives internalization of climate action commitments within business operations.

The emergence of the CSO as a mainstay in the C-suite also hints at the way firms are adjusting their business models to align with the transition to more sustainable practices. Martin Wainstein and Adam Bumpus define a business model (BM) as "a 'market device' that outlines the rationale of how an organization creates, delivers, and captures value." ${ }^{93}$ Wainstein and Bumpus also explain that innovation of the business model can occur without changing the underlying product or service of the firm, as "an innovative BM redefines the relationship between a product and the customer by fundamentally shifting the value proposition of the existing business. ${ }^{\prime 4}$ Business model theory is central to the transition to sustainable energy because firms must combat what the authors call "lock-in," which "is the metaphor to describe actors in a socio-technical regime that gain from perpetuating an existing technology at the expense of a new one, blocking incoming innovations." ${ }^{95}$ By breaking free from fossil fuels and incorporating sustainability into the value-creation process, new business models can be sustainable innovations themselves that may move the industry toward a new lock-in: renewable energy. ${ }^{96}$

update-december-2018/.

91 Miller and Serafeim, "Chief Sustainability Officers," 218.

92 Ibid.

93 Martin Wainstein and Adam Bumpus, "Business Models as Drivers of the Low Carbon Power System Transition: A Multi-Level Perspective,” Journal of Cleaner Production 126 (2016): 574.

94 Ibid., 575.

95 Ibid.

96 Ibid. 
Under the current pressures of global warming, proactive businesses have prioritized sustainability within their business models whereas others have remained steadfast in their use of fossil fuels. According to Wainstein and Bumpus, these businesses may be categorized as innovative BMs and incumbent BMs, respectively. Innovative BMs are incentivized to create a new value proposition through the potential for increased market share. This leads to new partnerships with investors, as well as reduced operational costs and avoidance of future industry disruptions given they themselves are the "disruptors." Wainstein and Bumpus note the case of SolarCity, a 2006 venture capital startup offering solar energy projects through PPAs. Now the largest solar energy provider in the U.S., SolarCity owns 41 percent of the solar market and was acquired by Tesla in $2016 .{ }^{97}$ The rise of SolarCity pressured incumbent U.S. utility companies to respond to this trend in the broader energy market. Ultimately, Wainstein and Bumpus conclude that "the more incumbents are forced to reconfigure their BM, the faster the power system undergoes a shift in its paradigm, further accelerating this process." ${ }^{\prime 8}$ The relationship of and distinction between innovative and incumbent BMs is foundational to understanding both how businesses implement greater climate action commitments and what the long-term aims of We Mean Business are.

\section{We Mean Business: Hewlett Packard Enterprise and The BMW Group}

The Hewlett Packard Enterprise Company (HPE) exemplifies how firms internalize the climate action commitments of We Mean Business. HPE is a multinational information technology (IT) company that separated from its counterpart HP Inc. in 2015 to focus on its technology and professional software services. Prior to the split, Hewlett Packard had appointed Nate Hurst as its first CSO in 2011, and he remains in the same role at HP Inc. today. Continuing the firm's legacy of sustainability, HPE hired Lara Birkes as CSO in 2016. ${ }^{99}$ Unlike Hurst, who was formerly a director of sustainability at Walmart

\footnotetext{
97 Seth Shobhit, "SolarCity vs. First Solar: Fierce Competition in the Solar Power Market," Investopedia, June 25, 2019, https://www.investopedia.com/news/solarcity-versus-first-solartsla-fslr/.

98 Wainstein and Bumpus, "Business Models as Drivers of the Low Carbon Power System Transition," 583.

99 Mike Hower, "Hewlett Packard Enterprise's CSO Lara Birkes on Sustainability," GreenBiz, July 12, 2016, https://www.greenbiz.com/article/lara-birkes-hpe-sustainability-compute.
} 
and had a predominantly business background, Birkes earned a Master's degree in international trade policy prior to holding leadership roles at the World Economic Forum, International Centre for Trade and Sustainable Development, and the We Mean Business subsidiary, WBCSD. ${ }^{100}$ By hiring a sustainability expert with extensive experience leading international climate projects, HPE signaled its commitment to innovative and corporate-led social development. Under Birkes' leadership, HPE joined RE100 by setting a goal of 50 percent renewable energy consumption by 2025 . Additionally, the firm claims to be "raising the bar by becoming the first company to establish a comprehensive supply chain management program that requires companies in their value chain to set science-based emissions reductions targets." ${ }^{101}$ The firm aims for 80 percent of its manufacturing suppliers to set science-based targets, which HPE will support through public tracking, independent third party verification, and capacity-building. ${ }^{102}$ Although HPE committed to the Science Based Targets initiative (SBTi) through We Mean Business, the supply chain emissions project reflects the efforts of HPE alone and is indicative of Birkes' leadership. HPE thus exemplifies a firm that has internalized the climate action commitments of We Mean Business and adopted an innovative BM that keeps it at the forefront of its industry when it comes to social and environmental stewardship.

Another key example of innovative corporate climate action is the BMW Group (BMW). While the automobile industry as a whole accounts for the largest share of fossil fuel consumption, BMW is regarded as one of the most sustainable firms in the world, ranked first on Corporate Knights' 2016 Global 100 most sustainable corporations index. ${ }^{103}$ BMW's efforts began in 2009, with

\footnotetext{
100 "Lara Birkes: Chief Sustainability Officer at HPE," International Centre for Trade and Sustainable Development, https://www.ictsd.org/about-us/lara-birkes.

101 Cliff Henson, "HPE Targets 100 Million Tons of Supply Chain $\mathrm{CO}_{2}$ e Reductions," Science Based Targets, https://sciencebasedtargets.org/2017/05/26/hpe-targets-100-million-tons-ofsupply-chain-co2e-reductions/.

102 "Living Progress Report: 2017," Hewlett Packard Enterprise, June 2018, https://www. hpe.com/us/en/pdfViewer.html?docId=a00048490\&parentPage=/us/en/living-progress/ report\&resourceTitle=HPE+Living+Progress+Report+2017, 16 .

103 Corporate Knights is a sustainable business magazine that publishes a ranking of the top 100 most sustainable corporations based on a review of over 4,000 firms from across the world with a market capitalization over two billion dollars. Similar to DJSI, this index may be subject to bias given its focus on large firms. See "About Us," Corporate Knights, https://www.corporateknights. com/us/about-us/; Ryan Hewlett, "BMW the Most Sustainable Corporation in the World, According to Corporate Knights," Salt, January 26, 2016, https://www.wearesalt.org/bmw-the-
} 
its adoption of a company-wide sustainability strategy that aimed to "establish sustainability along the entire value chain and in all its basic processes, and thus create added value for the company, the environment, and society." ${ }^{104}$ BMW's sustainability management statement highlights the company's reasoning: "We also believe that the manufacturer with the most efficient and resource-friendly production processes will be the future industry leader, offering its customers state-of-the-art solutions for sustainable individual mobility." ${ }^{05}$ The move to an innovative, sustainable BM reflects BMW's long-term effort to be the industry leader by decoupling from the current parameters of the fossil fuel lock-in. BMW's foresight to remodel its operations around the impending transition to renewable energy have established it as an innovative firm set to disrupt competition and preserve its status as a leader in the industry.

Since 2009, BMW has labored to construct and implement its sustainable business model. BMW hired its first Head of Sustainability Strategy and Management in 2011, Alexander Nick, who still serves in the role today. Similar to Birkes at HPE, Nick has a background in sustainability, as a former research associate on corporate sustainability management at IMD Business School and former director at SustainAbility Ltd., a London-based global strategy consultancy and think tank advising businesses on sustainability issues. ${ }^{106}$ Also in 2011, BMW founded its "i" series of plug-in electric vehicles, led by the flagship i3 and i8 models which began retail in 2013 and 2014, respectively, to compete with Tesla. Then, in 2016, BMW expanded the i series by introducing iPerformance, which started the transfer of BMW i technology to the BMW core brand through a fleet of plug-in hybrid variants of traditional models. ${ }^{107}$ Through innovative manufacturing, BMW has reduced its pervehicle energy consumption by 38 percent and $\mathrm{CO} 2$ emissions by 61.9 percent

most-sustainable-corporation-in-the-world-according-to-corporate-knights/.

104 Erskin Blunck, "Germany BMW's Sustainability Strategy of Evolution and Revolution towards a Circular Economy." In Towards a Circular Economy: Corporate Management and Policy Pathways, eds. Venkatachalam Anbumozhi and Jootae Kim (Jakarta: Economic Research Institute for ASEAN and East Asia, 2016), 76-77.

105 Ibid., 76.

106 "Alexander Nick," On-Purpose, https://onpurpose.org/en/our-community/en-alexandernick/.

107 Ibid. 
since 2006. ${ }^{108}$ Aside from sustainable designs in its production line, BMW actively engages in climate governance. During the Paris climate negotiations in December 2015, the auto manufacturer committed to RE100 with an interim goal of sourcing two-thirds of its electricity from renewables. Additionally, BMW actively aligns its annual sustainable value report with the $2030 \mathrm{UN}$ Sustainable Development Goals. As a result, BMW has earned a spot on CDP's A-list for eight consecutive years from 2010 to 2017, falling just short in 2018 with an A-. ${ }^{109}$ Moreover, the company reports cost savings of $€ 167$ million since 2006 from investments in environmental protection and improvements in resource efficiency. ${ }^{110}$ In sum, BMW has demonstrated its industry leadership by executing an innovative BM that places sustainability at its core.

The cases of HPE and BMW provide insight into the role of We Mean Business as well as corporate climate governance more generally. First, for businesses to make climate action commitments, they must be in the later stages of corporate social development. Given the voluntary, yet rigorous admission requirements for RE100, businesses must not only have the ambition to join these initiatives, but also the internal capacity to set feasible goals and execute them. Both HPE and BMW are long-standing industry stalwarts with strong leadership, as evidenced by their historical performance, allowing them to allocate and hire the necessary personnel, identify actionable goals, and invest capital into sustainability initiatives. By Mirvis and Googins' criteria, HPE and BMW would be in the innovation stage simply by joining various initiatives because they are partnering with other businesses and NGOs to address a social problem. Furthermore, by hiring a CSO or other executive responsible for leading their sustainability strategies, HPE and BMW fit within the innovation

\footnotetext{
108 "BMW at the 86th Geneva International Motor Show 2016," The BMW Group, March 1, 2016, https:/www.press.bmwgroup.com/global/article/detail/T0253602EN/bmw-at-the-86thgeneva-international-motor-show-2016.

109 "BMW Group Once Again Makes CDP List of World's Top Companies. Important

Recognition in the Field of Climate Protection," The BMW Group, October 25, 2018, https://www.press.bmwgroup.com/global/article/detail/T0275492EN/bmwgroup-once-again-makes-cdp-list-of-world\%E2\%80\%99s-top-companies-importantrecognition-in-the-field-of-climate-protection?language=en; "BMW AG," $C D P$, 2019, https://www.cdp.net/en/responses/1932?back_to=https\%3A\%2Fwww.cdp. net $\% 2$ Fen $\% 2$ Fresponses $\% 3$ Futf8\%3D\%25E2\%259C\%2593\%26queries $\% 255$ Bname $\% 255 \mathrm{D} \%$ 110 "Group-Wide Environmental Protection," The BMW Group, https://www.bmwgroup.com/ en/responsibility/group-wide-environmental-protection.html.
} 
stage. This is important because while the focus on larger companies does create bias, larger companies_- particularly industry leaders like BMW and HPEtend to be in these later stages of corporate social development. This enables them to more easily transition from an industry incumbent to an innovator. Moreover, smaller firms that seek to follow their peers and join these initiatives must make a concerted effort to create the internal capacity (assuming it does not already exist), which forces sustainability to be a predominant component of their business model even if their intent is to just enhance their brand image.

Second, the initiatives of We Mean Business are not cut and dry standards: rather, they promote innovation and entrepreneurship. Because the targets are set by the firm itself and the initiative only provides a baseline criteria with longer term goals (e.g. 100\% renewables by 2050), firms are encouraged to be ambitious in their targets and devise innovative ways of reaching them. Although some companies might do the bare minimum, the initiatives also foster competition between firms. For example, CDP's annual A-List recognizes the top two percent of firms taking action on climate change, water insecurity, and deforestation. ${ }^{111}$ Other credible organizations publish similar awards and scoring systems, ${ }^{112}$ which incentivize corporations to take bolder action and receive recognition among their peers, consumers, and host governments. In the case of HPE they set an aggressive emissions reduction target and designed a novel management system to monitor the emissions of their suppliers; they are proud to say they are the first company to do so. Likewise, HPE also was included on CDP's A-List and received the highest Supplier Engagement Rating_-accomplishments the firm proudly displays on its website and in its annual report. ${ }^{113} \mathrm{BMW}$ meanwhile was one of the first incumbent auto manufacturers to implement a full-fledged sustainability strategy and become an industry disruptor. Thus, We Mean Business initiatives can be seen as gateways to further climate action as long as firms allocate the necessary personnel and resources, provide free reign to innovate, are driven to outperform their peers, and are able to reap the financial rewards of

\footnotetext{
111 "World's Top Green Businesses Revealed in the CDP A List," CDP, January 22, 2018, https://www.cdp.net/en/articles/companies/worlds-top-green-businesses-revealed-in-the-cdp-alist.

112 See Windolph, “Assessing Corporate Sustainability Through Ratings,” 63.

113 "Living Progress Report," 15.
} 
sustainability efforts.

Third, the agency of specific individuals matters in corporate climate governance. When discussing corporations, it is easy to lose sight of the single actors who comprise these organizations. For HPE, hiring Birkes, an industry outsider with expertise in sustainability, enabled the firm to put its money where its mouth is and give her the authority to advance their sustainability efforts. Her experience, entrepreneurial drive, and passion for the environment as CSO led HPE to join RE100, set an ambitious emissions reduction target, and develop an industry-first supply chain emissions management system. Birkes is not alone among CSOs who are drivers of corporate climate action. In reference to Steve Howard, former CSO of IKEA, Miller and Serafeim explain that when Howard was hired, "he did not think that their strategy was visionary enough and that it did not clearly connect back to the business. Howard moved IKEA into the innovation stage by pulling together the senior leadership at IKEA to discuss how the company could be prepared for long-term world changes." ${ }^{114} \mathrm{Co}$-founder of RE100 and other climate initiatives, IKEA is now heralded as an industry leader in sustainability. In effect, CSOs and other sustainability professionals hold significant agency in advancing corporate sustainability and internalizing climate action in the business models of industry leading firms.

Fourth, innovative firms are in a unique position to drive change at the governmental level. One reason governments are hesitant to sign up for drastic emissions reductions targets simply comes down to economics. In a global economy, world leaders do all they can to maintain their country's competitive advantage and avoid decisions that could cripple their economy. When it comes to climate change and the energy transition, governments tend to have strong ties with incumbent businesses that benefit from fossil fuels. For example, Poland, the most recent host of the COP, produces over 80 percent of its energy from coal. Ironically, COP2 4 was sponsored by three state-owned coal companies, and Poland's pavilion at the conference was decorated in coal; they even gave away coal soap to visitors to support their clean coal agenda. ${ }^{115}$ For countries like Poland who are tethered to their national champions, innovative and sustainable businesses have the potential to disrupt incumbent fossil fuel conglomerates, as Wainstein and Bumpus demonstrate. When companies like HPE and BMW

114 Miller and Serafeim, "Chief Sustainability Officers," 212.

115 Shannon Osaka, "This Year's U.N. Climate Talks_-Brought to You by Coal?" Grist, December 4, 2018, https://grist.org/article/this-years-u-n-climate-talks-brought-to-you-by-coal/. 
make decisions to source their energy from renewables, it diverts market share away from incumbent energy companies and toward innovative providers of renewable energy such as SolarCity, which has already had a noticeable impact on U.S. utility companies. Building off the work of RE100, if enough companies source their energy from renewables, governments will eventually be forced to pivot away from the oil and gas giants, creating a new, sustainable lock-in.

Finally, profit maximization and combating climate change are not mutually exclusive. HPE and BMW show that a sustainable business model is the foundation of a successful firm in the post-Paris climate regime. Despite high overhead in the transition to a new energy source, the external benefits of a resource-friendly BM outweigh the upfront costs. In the case of BMW, the firm was driven by the need to stay at the forefront of the industry, especially with the emergence of Tesla in 2003. At the time, BMW was an incumbent firm, but it soon realized the innovative potential of the electric vehicle. As such, the firm announced its innovative sustainable business model in 2009 to stay ahead of competitors and new entrants into the market. Since 2011, BMW has recorded record sales for eight consecutive years while increasing their sales of electric and hybrid vehicles. ${ }^{116}$ Over the same time frame, BMW's dividend has grown from $€ 2.30$ in 2011 to $€ 3.50$ in 2019, which reflects the firm's ability to sustain profitability over time. ${ }^{117}$ In a similar vein, HPE's dividend has grown from $\$ 0.055$ in 2015 to $\$ 0.12$ in 2019 as the firm has focused on appealing to its environmentally-conscious customers. ${ }^{118}$ Since dividend growth reflects a firm's ability to sustain profits and reward investors, HPE's and BMW's significant growth shows the considerable value each firm has created. The fact that they have been able to invest strategically in their sustainable business models while increasing competitiveness demonstrates

\footnotetext{
116 "BMW Group Remains World's Leading Premium Automotive Company in 2018," The BMW Group, January 11, 2019, https:/www.press.bmwgroup.com/global/article/detail/ T0289883EN/bmw-group-remains-world\%E2\%80\%99s-leading-premium-automotivecompany-in-2018.

117 "BMW Shares," The BMW Group, https://www.bmwgroup.com/en/investor-relations/ bmw-\%20shares.html\#ace-428913679; "Dividend Growth Rate," Corporate Finance Institute, https://corporatefinanceinstitute.com/resources/knowledge/finance/dividend-growth-rate/. 118 "Dividend History," Hewlett Packard Enterprise, https://investors.hpe.com/stock/dividendhistory.
} 
that a successful corporation may nonetheless be sustainable. The coexistence of increased competitiveness and sustainable practices shows that We Mean Business, and corporate climate action more generally, comprise a viable governance regime within broader efforts to combat climate change.

\section{Conclusion}

As the international community moves forward following the signing of the Paris Agreement, We Mean Business demonstrates the prominence of the role of corporations in the pursuit of a more sustainable world. By bringing together the leading corporate climate initiatives, We Mean Business unifies the proactive business voice, scales the impact and scope of climate action commitments available to businesses, and facilitates the adoption and internalization of climate action in the strategy and operations of hundreds of the world's leading firms. While the long-run impact of these efforts on climate mitigation is a subject for further research, there is enough evidence to conclude that there is a credible corporate governance regime working to push the business case for climate action, accelerate adoption of renewables and science-based targets, advocate for greener policy frameworks, and establish sustainability as a core component of good business practice irrespective of industry.

The We Mean Business coalition qualifies as a credible governance regime by satisfying a number of criteria. First, We Mean Business influences firm behavior both through firms committing to climate action initiatives and cultivating innovative BMs that influence incumbent firms and the broader energy market. Climate action commitments such as RE100 support firms in transitioning to renewables and reducing $\mathrm{CO}_{2}$ emissions in line with science as a way to enhance public image, increase competitiveness, and be at the forefront of the energy transition. For large companies, to make such commitments requires significant financial, human capital, and time investment that must be built into the firm's business model and strategy. Furthermore, these commitments aid firms in advancing their corporate stewardship by encouraging companies to innovate and lead their industries.

Second, other actors in the international community recognize We Mean Business as a key player in the collective effort to combat climate change. Not only have global leaders from the UN and World Bank recognized RE100 for its work, but governments and international organizations also respect the initiative in the policymaking arena. In the EU, Australian Parliament, and UNFCCC, 
RE100 representatives and member firms were engaged with policymakers and influenced important decisions on renewable energy frameworks. Additionally, We Mean Business has partnered with major civil society NGOs and international organizations such as the WWF, WRI, and UN Global Compact, among others. Such partnerships with other credible organizations indicate that We Mean Business is one of the leading organizations for corporate climate governance and is working with leaders from other governance units in the international community to collectively combat climate change.

Finally, We Mean Business is composed of the leading actors in corporate climate governance who have been working on this issue for the past two decades. By uniting the top corporate NGOs, executives, and sustainability experts who each carry their own respective influence, We Mean Business is able to leverage the combined credibility of its members to continue advancing its agenda for years to come.

The credibility of We Mean Business as a governance regime has multiple implications for the study of international politics and global governance. Most importantly, the coalition bolsters support for the polycentric approach to climate change originally advocated for by Ostrom. While the structure of We Mean Business is conducive to collaboration at multiple levels and among a diverse range of actors, it is also illustrative of the agency of players outside the monocentric state-based system who are accomplishing real progress on climate. Furthermore, drawing on Keohane and Victor, We Mean Business and its stakeholders represent a specific regime among a loosely coupled set that constitutes the larger international regime complex. This suggests that the political will of entrepreneurs, business leaders, and sustainability experts is just as important as the effort put forth by policymakers. Therefore, Oreskes and Schendler's argument that businesses are not suited to solve climate change due to a few corrupt firms is akin to discounting all governments from climate solutions merely because some countries lack the appropriate political will. Moreover, their argument undercuts the polycentric approach needed to address climate change and disregards the writing on the wall that governments cannot go at it alone.

While the case of We Mean Business demonstrates the capacity of firms to undertake credible climate action, it also raises additional questions subject to further research. One unresolved issue surrounds the lasting 
impact of these corporate climate commitments and whether they are making a significant difference in regards to emissions reductions and the transition to renewable energy. Additional quantitative analysis of initiatives like RE100 and the specific commitments of firms would provide more insight into whether they are achieving tangible results. Another important avenue for research is how the corporate governance regime under We Mean Business compares to similar coalitions from other actors within the international community. For example, C40 Cities is a network of the world's megacities committed to addressing climate change. In fact, CDP is listed as a network partner of the initiative, suggesting some level of collaboration between C40 and the We Mean Business partner. ${ }^{119}$ Furthermore, scholars and practitioners could examine collaboration between coalitions and the notion of co-produced governance: how does the work of We Mean Business integrate into policy development at the government level or even into the work of other actors in the international climate regime? RE100's lobbying to create more favorable renewable energy policies in the EU is early evidence of integration, but initiatives and policies created by other governance units at the global level tend to occur independent of one another. How firms, cities, states, and international organizations may collaborate to synchronize and organize their efforts in ways that produce the best outcome for all parties would be an intriguing subject of inquiry as international climate governance continues to evolve.

119 "Our Partners and Funders," C40 Cities, https://www.c40.org/partners. 


\section{REFERENCES}

"100 Multinationals Commit to 100\% Renewable Electricity." United Nations Framework Convention on Climate Change. July 11, 2017. https:// unfcc.int/news/100-multinationals-commit-to-100-renewableelectricity.

Abbott, Kenneth. "Engaging the Public and Private in Global Sustainability Governance." International Affairs 88.3 (2012): 543-564. https://doi. org/10.1111/j.1468-2346.2012.01088.x.

Abbott, Kenneth and Duncan Snidal. "The Governance Triangle: Regulatory Standard Institutions and the Shadow of the State." In The Politics of Global Regulation, eds. Walter Mattli and Ngaire Woods. Princeton, NJ: Princeton University Press, 2009.

Åberg, Emma, and Stephanie Weckend. "Corporate Sourcing of Renewables: Market and Industry Trends." Edited by Stefanie Durbin and Steven Kennedy. REmade Index, 2018.

“About.” We Are Still In. https://www.wearestillin.com/about.

"About the Science Based Targets Initiative." Science Based Targets. https:// sciencebasedtargets.org/about-the-science-based-targets-initiative/.

"About Us." Corporate Knights. https://www.corporateknights.com/us/aboutus/.

Alarcon, Constant, Sam Kimmins, Marie Reynolds, Eleanor Dinnadge, Shailesh Telang, and Chiara Gilbert. "Approaching a Tipping Point: How Corporate Users are Redefining Global Electricity Markets." RE100 Progress and Insights Report, January 2018.

"Alexander Nick." On-Purpose. https://onpurpose.org/en/our-community/enalexander-nick/. 
Andrade, José Célio Silveira, and José Antônio Puppim de Oliveira. "The Role of the Private Sector in Global Climate and Energy Governance.” Journal of Business Ethics 130.2 (2015): 375-387.

Bartley, Tim. “Transnational Corporations and Global Governance.” Annual Review of Sociology 44 (2018): 145-165. https://doi.org/10.1146/ annurev-soc-060116-053540.

Blunck, Erskin. “Germany BMW’s Sustainability Strategy of Evolution and Revolution towards a Circular Economy." In Towards a Circular Economy: Corporate Management and Policy Pathways. Edited by Venkatachalam Anbumozhi and Jootae Kim. Jakarta: Economic Research Institute for ASEAN and East Asia, 2016, 75-92.

"BMW at the 86th Geneva International Motor Show 2016." The BMW Group, March 1, 2016. https://www.press.bmwgroup.com/global/article/detail/ T0253602EN/bmw-at-the-86th-geneva-international-motor-show-2016.

“BMW Group Once Again Makes CDP List of World's Top Companies. Important Recognition in the Field of Climate Protection." The BMW Group. October 25, 2018. https://www.press.bmwgroup.com/global/ article/detail/T0275492EN/bmw-group-once-again-makes-cdp-list-ofworld $\%$ E2\%80\%99s-top-companies-important-recognition-in-the-fieldof-climate-protection.

"BMW Group Remains World's Leading Premium Automotive Company in 2018." The BMW Group. January 11, 2019. https://www.press. bmwgroup.com/global/article/detail/T0289883EN/bmw-group-remainsworld\%E2\%80\%99s-leading-premium-automotive-company-in-2018.

"BMW Shares." The BMW Group. https://www.bmwgroup.com/en/investorrelations/bmw-\%20shares.html.

Cerutti, Furio. “Two Global Challenges to Global Governance.” Global Policy 3.3 (2012): 257-271. https://doi.org/10.1111/j.1758-5899.2011.00155.x. 
Cole, Daniel. "Advantages of a Polycentric Approach to Climate Change Policy." Nature Climate Change 5 (2015): 114-118. https://doi. org/10.1038/nclimate2490.

“Companies.” RE100. http://there100.org/companies.

"Companies." We Mean Business. https://www.wemeanbusinesscoalition.org/ companies/.

“Companies: H\&M Hennes \& Mauritz AB.” We Mean Business. https://www. wemeanbusinesscoalition.org/companies/\#pageNum=8.

"COP24: Leading Companies Demonstrate Climate Action, Call for Policy Ambition.” We Mean Business. December 12, 2018. https://www. wemeanbusinesscoalition.org/blog/cop24-leading-companiesdemonstrate-climate-action-call-for-policy-ambition/.

"CSO Backstory: How Chief Sustainability Officers Reached the C-Suite." Weinreb Group. September 2011. https://weinrebgroup.com/wpcontent/uploads/2011/09/CSO-Back-Story-by-Weinreb-Group.pdf.

Dinnadge, Elanor, Constant Alarcon, and Marie Reynolds. "Moving to Truly Global Impact: Influencing Renewable Electricity Markets.” RE100 Progress and Insights Report, November 2018. http://media.virbcdn. com/files/fd/868ace70d5d2f590-RE100ProgressandInsightsAnnualRep ortNovember2018.pdf.

“Dividend Growth Rate." Corporate Finance Institute. 2019. https:// corporatefinanceinstitute.com/resources/knowledge/finance/dividendgrowth-rate/.

“Dividend History." Hewlett Packard Enterprise. 2019. https://investors.hpe. com/stock/dividend-history. 
Falkner, Robert. Business Power and Conflict in International Environmental Politics. New York: Palgrave Macmillan, 2008.

Farnworth, Emily. "Briefing Report 2015.” Edited by Clare Saxon. RE100. January 2015. http://media.virbcdn.com/files/d4/0d785368ea4e15c5RE100briefing-reportre100websitev3.pdf.

Fransen, Luc. "Beyond Regulatory Governance?: On the Evolutionary Trajectory of Transnational Private Sustainability Governance.” Ecological Economics 146 (2018): 772-777. https://doi.org/10.1016/j.ecolecon.2018.01.005.

Green, Jessica. Rethinking Private Authority: Agents and Entrepreneurs in Global Environmental Governance. Princeton, NJ: Princeton University Press, 2014.

“Group-Wide Environmental Protection.” The BMW Group. https://www. bmwgroup.com/en/responsibility/group-wide-environmental-protection. html.

H\&M Group. "Sustainability Reporting: Indexes and Rankings.” H\&M Group. https://sustainability.hm.com/en/sustainability/about/what-others-say/ indexes-rankings.html.

Hashmi, M. Anaam, Amal Damanhouri, and Rana Divya. "Evaluation of Sustainability Practices in the United States and Large Corporations." Journal of Business Ethics 127.3 (2015): 673-681. https://doi. org/10.1007/s10551-014-2056-4.

Henson, Cliff. "HPE Targets 100 Million Tons of Supply Chain $\mathrm{CO}_{2} \mathrm{e}$ Reductions." Science Based Targets. https://sciencebasedtargets. org/2017/05/26/hpe-targets-100-million-tons-of-supply-chain-co2ereductions/. 
Hewlett, Ryan. "BMW the Most Sustainable Corporation in the World, According to Corporate Knights.” Salt. January 26, 2016. https://www. wearesalt.org/bmw-the-most-sustainable-corporation-in-the-worldaccording-to-corporate-knights/.

Hickmann, Thomas. Rethinking Authority in Global Climate Governance: How Transnational Climate Initiatives Relate to the International Climate Regime. New York: Routledge, 2016.

“How We're Funded.” Science Based Targets. https://sciencebasedtargets.org/ funders.

Hower, Mike. "Hewlett Packard Enterprise’s CSO Lara Birkes on Sustainability." GreenBiz. July 12, 2016. https://www.greenbiz.com/ article/lara-birkes-hpe-sustainability-compute.

Hsueh, Lilly. "Transnational Climate Governance and the Global 500:

Examining Private Actor Participation by Firm-Level Factors and Dynamics." International Interactions 43.1 (2017): 48-75. https://doi.or g/10.1080/03050629.2016.1223929.

“IKEA.” RE100. June 2016. http://there100.org/ikea/.

“Joining Criteria." RE100. January 2017. http://media.virbcdn.com/files/45/ db8335e1 ef4b851c-RE100JoiningCriteria.pdf.

"Join Us at GreenBiz.” WBCSD. http://promo.wbcsd.org/greenbiz-2019/.

Keohane, Robert, and Elinor Ostrom, eds. Local Commons and Global Interdependence: Heterogeneity and Cooperation in Two Domains. London: Sage Publications, 1995.

Keohane, Robert, and David Victor. "The Regime Complex for Climate Change." Perspectives in Politics 9.1 (2011): 7-23. https://www.jstor.org/ stable/41622723. 
Khanna, Parag. "These 25 Companies are More Powerful than Many Countries." Foreign Policy. March 15, 2016. http://foreignpolicy.com/2016/03/15/ these-25-companies-are-more-powerful-than-many-countriesmultinational-corporate-wealth-power/.

Kollman, Kelly. "The Regulatory Power of Business Norms: A Call for a New Research Agenda.” International Studies Review 10.3 (2008): 397-419. https://doi.org/10.1111/j.1468-2486.2008.00798.x.

"Lara Birkes: Chief Sustainability Officer at HPE." International Centre for Trade and Sustainable Development. https://www.ictsd.org/about-us/lara-birkes.

Light, Sarah, and Erica Orts. "Parallels in Public and Private Environmental Governance." Michigan Journal of Environmental and Administrative Law 5.1 (2015): 1-72.

“Living Progress Report: 2017.” Hewlett Packard Enterprise. June 2018. https://www.hpe.com/us/en/pdfViewer. html?docId=a00048490\&parentPage=/us/en/living-progress/ report\&resourceTitle=HPE+Living+Progress+Report+2017.

Makower, Joel. "Two Steps Forward: A Powerhouse Corporate Climate Coalition Says, 'We Mean Business.'” GreenBiz. June 9, 2014. https://www. greenbiz.com/blog/2014/06/09/powerhouse-climate-coalition-we-meanbusiness.

Milan, Babic, Jan Fichtner, and Eelke Heemskerk. "States Versus Corporations: Rethinking the Power of Business in International Politics." The International Spectator 52.4 (2017): 20-43. https://doi.org/10.1080/0393 2729.2017.1389151.

Miller, Kathleen and George Serafeim. "Chief Sustainability Officers: Who Are They and What Do They Do?” In Leading Sustainable Change: An Organizational Perspective, eds. Rebecca Henderson, Ranjay Gulati, and Michael Tushman. Oxford, UK: Oxford University Press, 2015. 
Mirvis, Philip and Bradley Googins. "Stages of Corporate Citizenship: A Developmental Framework." The Center for Corporate Citizenship at Boston College, 2007.

Nye, Joseph S., Jr. "Multinationals in World Politics." Foreign Affairs 53.1 (1974): 153-175. https://www.jstor.org/stable/20039497.

Oreskes, Naomi, and Auden Schendler. "Corporations Will Never Solve Climate Change." Harvard Business Review. December 4, 2015. https:// hbr.org/2015/12/corporations-will-never-solve-climate-change.

Osaka, Shannon. "This Year's U.N. Climate Talks_-Brought to You by Coal?" Grist. December 4, 2018. https://grist.org/article/this-years-u-nclimate-talks-brought-to-you-by-coal/.

Ostrom, Elinor. A Polycentric Approach for Coping with Climate Change. Washington, DC: The World Bank, 2009.

"Our Partners." We Mean Business Coalition. https://www. wemeanbusinesscoalition.org/partners/.

“Our Partners and Funders.” C40 Cities. https://www.c40.org/partners.

Strange, Susan. The Retreat of the State: The Diffusion of Power in the World Economy. Cambridge, UK: Cambridge University Press, 1996.

Wei, David, Edward Cameron, Samantha Harris, Emilie Prattico, Gareth Scheerder, and Joanna Zhou, et al. "The Paris Agreement: What it Means for Business.” We Mean Business. June 28, 2016. https://www. bsr.org/reports/BSR_WeMeanBusiness_Business_Climate_Paris_ Agreement_Implications.pdf.

"What Investors Are Saying." Science Based Targets. https://sciencebasedtargets. org/what-investors-are-saying/. 
"What is Talanoa?" United Nations Framework Convention on Climate Change. https://talanoadialogue.com/background.

Windolph, Sarah. "Assessing Corporate Sustainability Through Ratings: Challenges and Their Causes." Journal of Environmental Sustainability 1.1 (2011): 61-80.

"World First as 100 Multinationals Target 100\% Renewable Electricity." RE100. July 10, 2017. http://there100.org/news/14257837.

"World's Top Green Businesses Revealed in the CDP A List." CDP. January 22, 2018. https://www.cdp.net/en/articles/companies/worlds-top-greenbusinesses-revealed-in-the-cdp-a-list.

Yamin, Farhana and Joanna Depledge. The International Climate Regime: A Guide to Rules, Institutions, and Procedures. Cambridge, UK: Cambridge University Press, 2004. 